\title{
Structural Features of the Legume Lectins
}

\author{
マメ科レクチンの構造における特徵
}

\author{
Hamelryck, Thomas W.* ; Loris, Remy ; Bouckaert, Julie ; and Wyns, Lode \\ Laboratorium voor Ultrastructuur, Vlaams Interuniversitair Instituut voor Biotechnologie \\ Vrije Universiteit Brussel, Paardenstraat 65, B-1640 Sint-Genesius-Rode, Belgium \\ FAX : 32-2-3590289, E-mail : thamelry@vub.ac.be
}

Key Words : lectin-like proteins, legume lectins, protein-sugar interactions, quaternary structure, $x$-ray crystallography

\begin{abstract}
The legume lectins are a family of carbohydrate binding proteins found in the Leguminosae plants and are used as a model system for studying protein-carbohydrate interactions. The different legume lectins show a remarkable range of sugar specificities, despite the high sequential and structural similarity of their subunits. Moreover, their subunits can associate into a number of different multimers. The unique variability of quaternary structure has implications for the formation of cross-linked lattices and binding of hydrophobic ligands.
\end{abstract}

\section{A. Introduction}

The legume lectins are a family of sugar binding proteins found in the seeds, and to a lesser extent in the stems and the leaves, of plants belonging to the Leguminosae family (1, 2 ), although recently homologues in another plant family and animals have been described. They have been used for decades as a model system for the study of protein-sugar interactions, because they show an amazing variety of sugar specificities and are easy to obtain and purify. Over the years, a quite impressive amount of structural data has been gathered. Fundamental insights obtained from studying the legume lectin model system can often be readily applied to lectins outside this family, e.g. the pharmaceutically important C-type lectins and galectins (3). Indeed, well-established concepts like subsite multivalency (4, 5) or the formation of cross-linked lattices (for a review, see (6)) were first observed in legume lectin studies and proved to be valid outside the legume lectin family. This review will focus on the structure of the legume lectins, indicating where data is still lacking and making comparisons with other lectin families.
要 旨

マメ科レクチンはマメ科植物中に見い出される糖結合性夕 ンパク質ファミリーで、タンパク質-糖相互作用の研究における モデルシステムとして用いられている。種々のマメ科レクチン は、サブユニットの配列と構造の類似性の高さにもかかわら ず、著しく広い範囲の糖特異性を示す。さらに、それらのサブ ユニットは多くの異なる多量体に会合できる。四次構造の類の 無い多様性は、架橋格子の形成や疎水的なリガンドとの結合と 密接に関連している。

\section{A. 序 論}

マメ科レクチンはマメ科(Leguminosae)に属する植物の種 子、および種子に比べて量は少ないが茎や葉にも見い出される 糖結合性タンパク質ファミリーであり $(1 、 2) 、$ 最近では他の植物 ファミリーや動物においても相同タンパク質が報告されてい る。マメ科レクチンは驚異的なまでに多様な糖特異性をもち、 容易に入手、精製できることから、この数十年タンパク質-糖相 互作用の研究におけるモデルシステムとして用いられてきた。 これまでに目ざましい量の構造的なデータが集められている。 マメ科レクチンモデルシステムの研究から得られた基礎的な知 見は、このファミリー以外のレクチン、例えば薬学的に重要な C型レクチンやガレクチンにもただちに応用できる(3)。実際、 サブサイトの多価性(4、5)や架橋格子の形成(総説6)のようによ く確立された概念はマメ科レクチンにおいて初めて観察され、 マメ科レクチン以外にも十分当てはまる説であることが証明さ れた。この総説では、マメ科レクチンの構造に焦点をあて、ど んな部分のデータが不足しているかを示し、また他のレクチン ファミリーとの比較を行う。

\footnotetext{
* To whom correspondance should be addressed.

Abbreviations used : $\alpha$ AI, $\alpha$-amylase inhibitor (Phaseolus vulgaris) ; aSFP, Acidic seminal fluid protein ; DB58, Horse gram (Dolichos biflorus) stem- and leaves lectin; DBL, Horse gram (Dolichos biflorus) seed lectin; ERGIC-53, Type I membrane protein of the endoplasmatic reticulumGolgi intermediate compartment; Con A, Jack bean (Canavalia ensiformis) lectin; EcorL, West Indian coral tree (Erythrina corallodendron) lectin; GS4, Griffonia simplicifolia (now Bandeirea simplicifolia) isolectin 4; LOL, Lathyrus ochrus isolectins ; PHA-E, Erythroagglutinating common bean (Phaseolus vulgaris) agglutinin ; PHA-L, Leucoagglutinating common bean (Phaseolus vulgaris) agglutinin; PNA, Peanut (Arachis hypogaea) agglutinin; PSP-I/PSP-II, Porcine seminal plasma proteins I and II; SBA, Soybean (Glycine max) agglutinin; VIP36, Vesicular integral membrane protein $(36 \mathrm{kD})$
} 


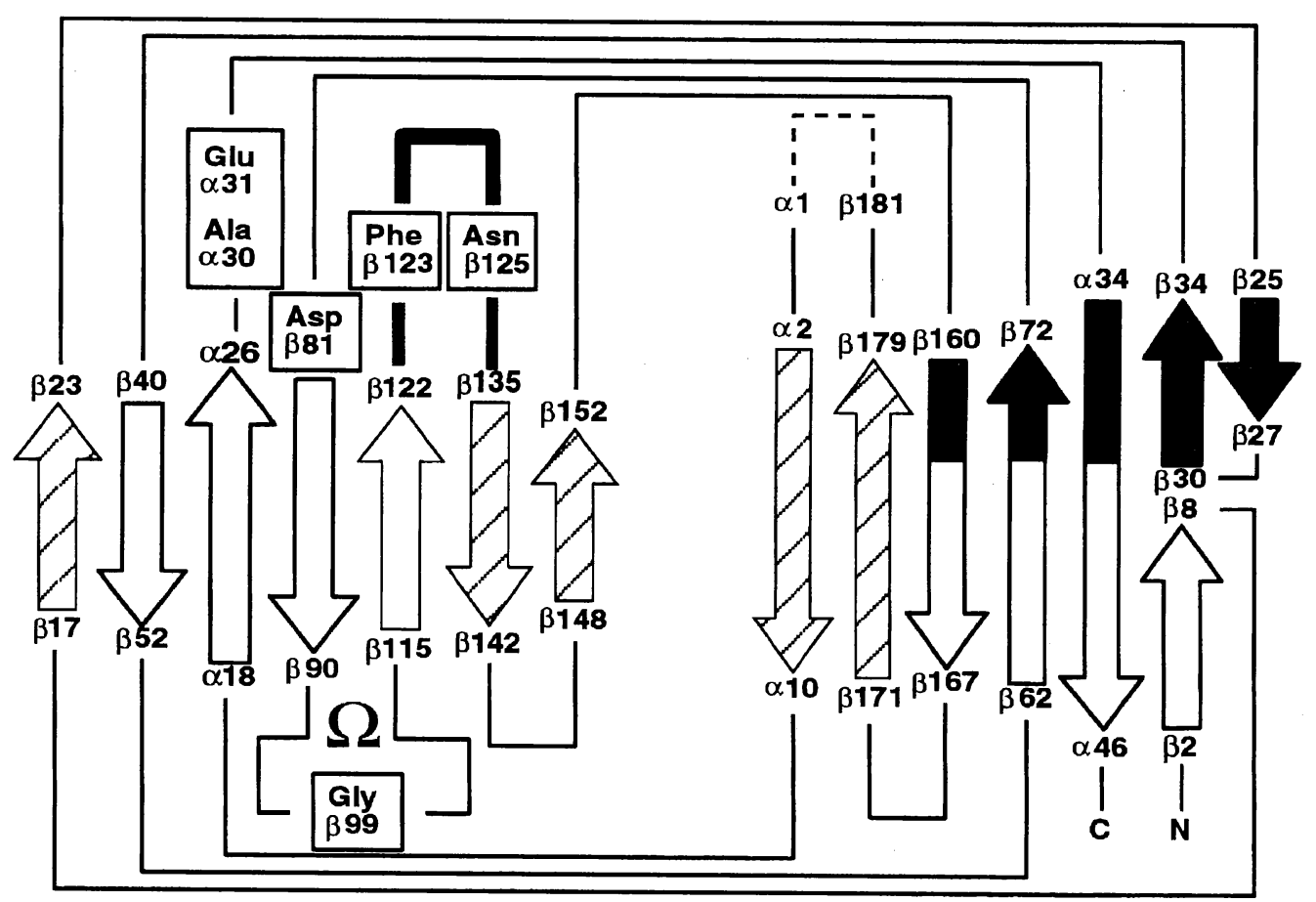

Fig. 1. Topology diagram of a typical legume lectin monomer (lentil lectin, PDB entry 1LES (82)). $\beta$-sheets are shown as arrows, connecting loops as simple lines. The monomer consists of a flat six strand $\beta$-sheet (shown right), a curved seven strand $\beta$-sheet (shown left) and a small connecting five strand $\beta$-sheet (shown in gray). The topology is related to the jellyroll fold, with three additional inserts (shown as hatched

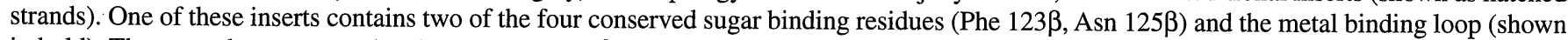
in bold). The two other conserved residues are Asp $81 \beta$ (involved in the Ala-Asp cis-peptide bond) and Gly $99 \beta$ (present in a large $\Omega$-loop that packs against the front sheet). Ala $30 \alpha$ and Glu $31 \alpha$ belong to the monosaccharide specificity loop. Lentil lectin belongs to the Glc/Man specific Vicieae tribe lectins and is proteolytically cleaved at position 181 (shown as a dotted line), resulting in a two-chain lectin (chains $\alpha$ and $\beta$ ).

\section{B. The Legume Lectin Monomer}

The different legume lectin monomers are extremely similar, and their structure can be described as a $\beta$-sandwich consisting of a flat, six stranded sheet (the back sheet), and a curved, seven stranded sheet (the front sheet). A small third $\beta$ sheet, consisting of five strands, holds the two larger sheets together (7). The sugar binding site is located on the concave side of the $\beta$-sandwich, formed by the curved front sheet, next to a double metal binding site. The topology of the monomer is related to the right handed class I' jellyroll fold (8), but it contains three insertions, one of which is directly involved in sugar and metal binding (see Fig. 1). Essentially the same topology is found in the galectins $(9,10)$ and in serum amyloid protein $(11)$, both of which are lectins. Many sugar binding or processing proteins have a topology related to the jellyroll fold (including $\beta$-Dglucanase (12), the galectins, the legume lectins, serum amyloid protein, PNGase F $(13,14)$, cellobiohydrolase I (15) and two members of the spermadhesin family (16-18)) and sugar binding always seems to occur on the concave side of the $\beta$ sandwich, on the side of the front sheet in the legume lectins $(13,19)$. Norris et al. (13) suggested that the combination of this curved $\beta$-sheet and the connecting loops that fold over the

\section{B. マメ科レクチンの単量体}

種々のマメ科レクチンの単量体はきわめて類似していて、 6本のポリペプチド主鎖がつくる平らな面(背面折り紙構造)と7本 の主鎖がつくる湾曲した面(前面折り紙構造)から成り、それらの 構造は $\beta$-サンドイッチと呼ばれる。3番目の小さな $\beta$-シートは 5本の主鎖から成り、2つの大きな面を互いに固定している(7)。 糖結合部位は、湾曲した前面折り紙構造によって形成される $\beta$ サンドイッチのくほんだ側にあり、2つの金属結合部位の近辺に 位置している。単量体のトポロジーは右回りのI型ゼリーロール 構造(8)に関連しているが、それは3つの挿入を含み、そのうちの 1つは糖および金属結合に直接かかわっている(図1)。本質的に同 じトポロジーが、ともにレクチンであるガレクチン $(9 、 10)$ およ び血清アミロイドタンパク質(11)においても見い出されている。

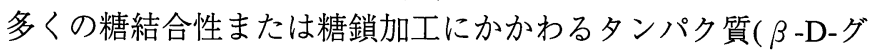
ルカナーゼ(12)、ガレクチン、マメ科レクチン、血清アミロイド タンパク質、PNGase F(13、14)、セロビオヒドロラーゼ I (15)、 およびスパームアドヘジンファミリー(16-18)の2つのメンバーを 含む)は、ゼリーロール構造と関連したトポロジーを持ち、糖と の結合はどれも、マメ科レクチンでは前面折り紙構造側にある $\beta$-サンドイッチのくぼんだ部分で起こっているようである(13、 19)。Norrisらは、湾曲した $\beta$-シートと2つの面を折り畺む結合 ループの組み合わせが糖結合にとりわけ都合がよいということ 


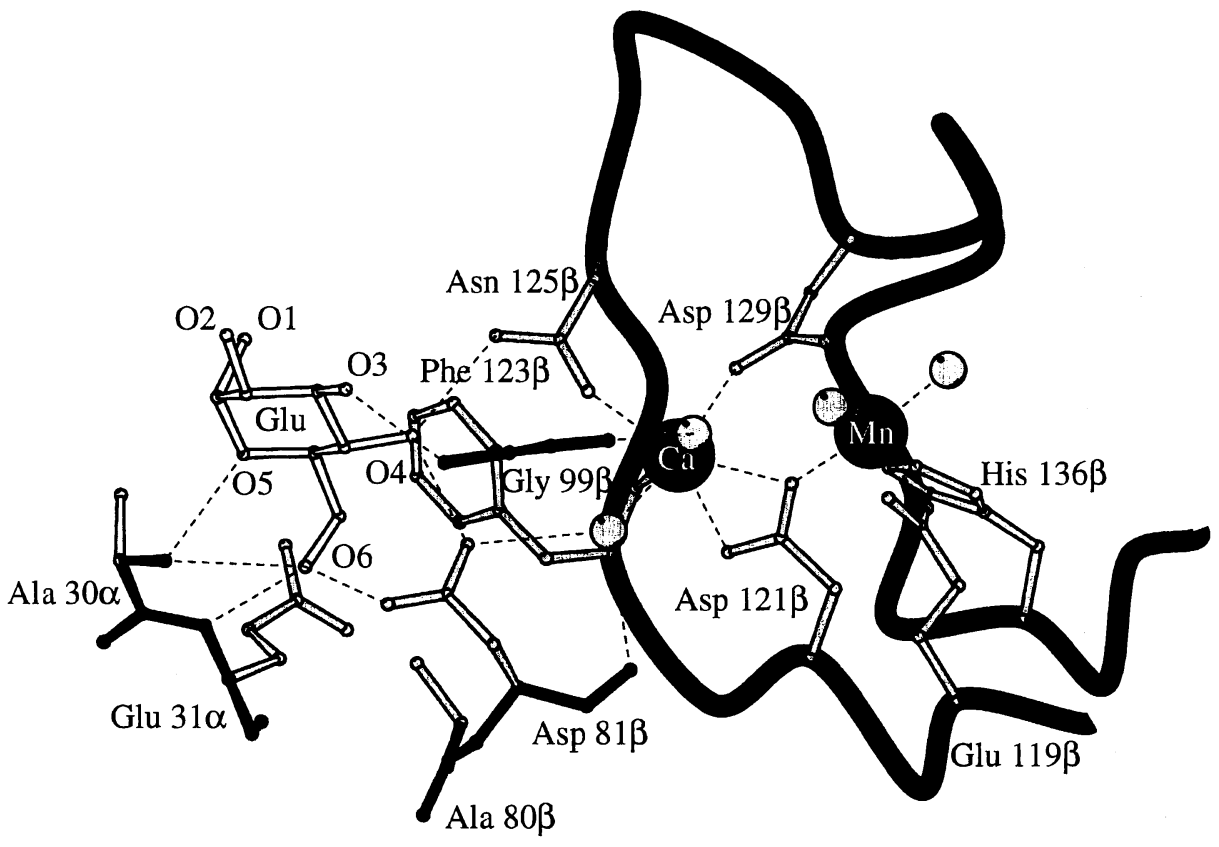

Fig. 2. The monosaccharide and metal binding sites of lentil lectin (PDB entry 1LES (82)), with a glucose bound in the monosaccharide binding site. The two metal ions $\left(\mathrm{a} \mathrm{Ca}^{2+}\right.$ ion and a transition metal ion, here shown as a $\mathrm{Mn}^{2+}$ ion) are each ligated by four residues and two water molecules. The $\mathrm{Ca}^{2+}$ ion interacts with the four sugar binding residues : Phe $123 \beta$ and Asn $125 \beta$ are direct metal ligands, while Asp $81 \beta$ and Gly $99 \beta$ interact via water molecules (shown as light gray spheres). Phe $123 \beta$ is involved in a hydrophobic contact, while the other sugar binding residues hydrogen bond to the sugar. Only the monosaccharide specificity loop (Ala $30 \alpha$-Glu $31 \alpha$ ) differs substantially between lectins belonging to different specificity groups. Fig. 2 and 3 were made with MOLSCRIPT (83).

sheet is especially suited to carbohydrate binding. The similarity between the topology of the legume lectins, serum amyloid protein and the galectins may thus be the result of convergent evolution. Moreover, the $\beta$-sandwich architecture may also be especially suited to generating a variety of quaternary structures, which is important for binding multivalent epitopes or crosslinking ligands (see paragraph D).

\section{Sugar Binding by Legume Lectins}

The legume lectins have developed an ingenious framework for binding mono- and oligosaccharides. This framework consists of a conserved monosaccharide binding site in which four conserved residues confer affinity, a variable loop that confers monosaccharide specificity and a number of subsites that harbor additional sugar residues or hydrophobic groups.

The legume lectins can be subdivided into five groups according to the specificity of the conserved monosaccharide binding site (1) : Fuc specific, GlcNAc/GlcNAc( $\beta 1-4)$ GlcNAc specific, Glc/Man specific, Gal/GalNAc specific, and those that do not bind any simple monosaccharides. Within these groups, some idiosyncratic representatives may be found, e.g. DBL which binds GalNAc but not Gal (20). At present, structural data is only available for members of the latter three groups. In the monosaccharide binding site (see Fig. 2), three of the four conserved residues (the Gly-Asn-Asp triad) hydrogen bond to the sugar, while a fourth aromatic residue stacks against the hydrophobic part of the sugar. These four residues are held in the correct position by two bound metal ions $\left(\mathrm{a} \mathrm{Ca}^{2+}\right.$ ion and a transition metal ion), either directly or via water molecules. Most
を提唱した(13)。マメ科レクチン、血清アミロイドタンパク質、 およびガレクチンのトポロジー間の類似性は、したがって、収 斂進化の結果であろう。さらに $\beta$-サンドイッチの構成は、多価 のエピトープとの結合やリガンドの架橋に重要な、四次構造の 多様性を生じさせるためにも特に適しているのかもしれない(D. 参照)

\section{C. マメ科レクチンによる糖との結合}

マメ科レクチンは、単糖およびオリゴ糖鎖結合に対する精 巧な骨格を発達させてきた。この骨格は、保存された残基に よって親和性を示すような単糖結合部位、単糖特異性を与える 可変的なループ、および他の糖残基や疎水基と結合する多くの サブサイトから成る。

マメ科レクチンは、保存された単糖結合部位の特異性に よって、さらに5つのグループに分けられる(1)。すなわち、Fuc 特異的、GlcNAc/GlcNAc( $\beta 1-4)$ GlcNAc特異的、Glc/Man特異的、 Gal/GalNAc特異的、およびどんな単糖とも結合しないレクチン である。これらのグループの中には、たとえばGalNAcには結合 するがGalには結合しないDBLのような(20)、いくつかのきわめ て独特な例もある。現在のところ、構造的なデー夕は後者 3 グ ループについてしか得られていない。単糖結合部位において(図 2)、4つの保存された残基のうち 3 つ(Gly-Asn-Aspの3つ組)が糖と 水素結合し、一方、第 4 番目の芳香族残基は糖の疎水的部分に重 なる。これら4残基は、結合した 2 個の金属イオン $\left(1\right.$ 個の $\mathrm{Ca}^{2+}$ と 1 個の遷移金属イオン)によって直接、または水分子を介して、正 
Trends in Glycoscience and Glycotechnology Vol.10 No.55 (September 1998) pp.349-360

importantly, the metal ions stabilize an unusual cis-peptide bond between an Ala and an Asp residue, thereby positioning the Asp side chain in the correct position for sugar binding (21). Gal and Glc can both interact favorably with the four conserved residues, but must adopt different orientations relative to these residues due to their different conformations at $\mathrm{O} 4$. Hence, in Glcspecific legume lectins like the Vicieae lectins or Con A O4 and O6 interact with the triad (22-24), while in Gal specific legume lectins like EcorL, SBA or PNA O3 and O4 interact $(7,25,26)$. Which of the two will actually bind is determined by the socalled specificity loop (Ala $30 \alpha-$ Glu $31 \alpha$ in the Glc specific lentil lectin, see Fig. 2), by making it sterically impossible for the other sugars to position themselves favorably relative to the four conserved residues, and by providing additional affinity for the correct sugar (27). It is expected that this scheme will also be valid for the Fuc and GlcNAc specific legume lectins, for which structural data is still lacking. Homology modeling of the Fuc specific Ulex europaeus lectin I and docking of Fuc in the modeled monosaccharide binding site resulted in four possible binding modes, either involving $\mathrm{O} 4$ and $\mathrm{O} 3$, or $\mathrm{O} 2$ and $\mathrm{O} 3$ (28). Unequivocal elucidation of its mode of binding thus has to await the structure determination of a sugar complex.

Next to the monosaccharide binding site, subsites may be present that harbor additional ligands like hydrophobic aglycons or specific monosaccharides. The interactions that these subsites provide are too weak to bind these groups independently, and only attached to a central sugar residue bound in the monosaccharide binding site role becomes important. At present, three different subsites have been described. The exact specificity of these subsites may vary from lectin to lectin. The first subsite binds hydrophobic groups (Con A (29)), the second binds both monosaccharides and hydrophobic groups (Fuc in EcorL (30), hydrophobic groups in the Vicieae lectins $(23,31,32)$, the $N$ acetylgroup of GalNAc in DBL (33)) and the third binds monosaccharides (Fuc in the Vicieae lectins $(34,35)$, Man in Con A $(36,37)$, Fuc in DBL $(33,38))$.

Only two structures are available from members of the complex specificity group, namely GS4 (39-41) and PHA-L (42). In the case of the GS4 a complex with the Le ${ }^{\mathrm{b}}$ sugar $(\operatorname{Fuc}(\alpha 1-2) \mathrm{Gal}(\beta 1-3)[\mathrm{Fuc}(\alpha 1-4)] \mathrm{GlcNAc})$ is available. As in the Gal-specific legume lectins, the Gal residue is bound in the monosaccharide binding site of GS4 and interacts similarly with the four conserved residues. However, the specificity loop of GS4 adopts a distinctly different conformation and instead interacts with the $\alpha(1-4)$ linked Fuc residue. In other words, the interactions between the specificity loop and the monosaccharide in the monosaccharide binding site have been replaced by interactions between the specificity loop and a secondary sugar residue, which explains why GS4 does not bind monosaccharides. Whether a similar explanation holds for the other members of the complex specificity groups remains to be seen.
しい空間位置に保持されている。最も重要なことは、金属イオ ンがAla残基とAsp残基間の珍しいシスーペプチド結合を安定化 し、それによってAsp側鎖が糖に結合するための正しい位置へ配 置されることである(21)。GalおよびGlcはともに保存された4残 基と有利に相互作用できるが、O4位の立体配座の違いにより、 これらの残基に対して 異なる配向をとらなければならない。し たがって、ソラマメ属(Vicieae)レクチンやCon AのようなGlc特 異的マメ科レクチンにおいては、O4およびO6位がGly-Asn-Asp の3つ組と相互作用するが(22-24)、一方、EcorL、SBA、および PNAのような $\mathrm{Gal}$ 特異的マメ科レクチンでは、O3およびO4位が 相互作用する(7、25、26)。2種類のどちらの糖が実際に結合する かは、いわゆる特異性ループ(Glc特異的レンチル（レンズマ メ）レクチンではAla30 $\alpha$-Glu31 $\alpha$ 、図2参照)が、保存された4残 基に対して他の糖が結合配置をとることを立体的に不可能に し、また正しい糖に対してさらに親和性を与えることによって 決定する(27)。この図式は、構造的デー夕はまだ得られていない が、FucおよびGlcNAc特異的マメ科レクチンに対しても当ては まることが予想される。Fuc特異的ハリエニシダ(Ulex europaeus) レクチンIの相同性に基づく構造予測（ホモロジーモデリング） と、単糖結合部位モデルにFucを結合させることによって、O4 とO3、またはO2とO3のいずれかを含む4種類の可能な結合様式 性が示された(28)。糖複合体の構造の決定により、この結合様式 がはっきりと解明されるであろう。

単糖結合部位の近辺に、疎水的アグリコンや他の特異的単 糖のような、別のリガンドと結合するサブサイトが存在する場 合がある。サブサイトが与える相互作用は非常に弱いため、こ れらの基は単独では結合できず、単糖結合部位に結合した中心 の糖残基に付随する場合にのみ、その役割が重要になってく る。現在のところ、3つの異なるサブサイトが報告されている。 これらのサブサイトの詳細な特異性はレクチンによって変化す るようである。第1のサブサイトは蹯水基に結合し(Con A(29))、 第2は単糖と疎水基の両方に結合する(EcorLにおけるFuc(30)、ソ ラマメ属レクチンにおける疎水基(23、31、32)、DBLにおける GalNAcのN-アセチル基(33))。そして第3のサブサイトは単糖と 結合する(ソラマメ属レクチンにおけるFuc(34、35)、Con Aにお けるMan(36、37)、DBLにおけるFuc(33、38))。

複雑な特異性をもつグループの構成員の中で、GS4(39-41) およびPHA-L(42)の2つの構造だけが現在利用できる。GS4の場 合、 $\mathrm{Le}^{\mathrm{b}}$ 糖鎖 $(\mathrm{Fuc}(\alpha 1-2) \mathrm{Gal}(\beta 1-3)[\mathrm{Fuc}(\alpha 1-4)] \mathrm{GlcNAc})$ との複合体が 有効である。Gal特異的マメ科レクチンの場合と同様に、Gal残 基はGS4の単糖結合部位に結合し，保存された4残基と相互作用 する。しかし、GS4の特異性ループは明らかに異なるコンフォ メーションをとり、代わりに $\alpha 1-4$ 結合したFucと相互作用する。 言い換えれば、特異性ループと単糖結合部位に結合した単糖の 間の相互作用は、特異性ループと二番目の糖残基の間の相互作 用に取って代わられたことになり、これによってなぜGS4が単 糖と結合しないかということが説明できる。同様の説明が, 複 雑な特異性をもつグループの他の構成員にも成り立つかどうか は、まだ明かでない。 


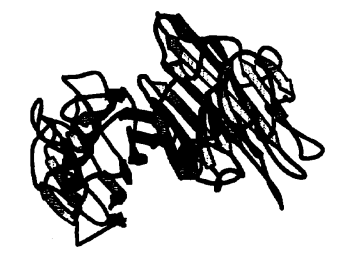

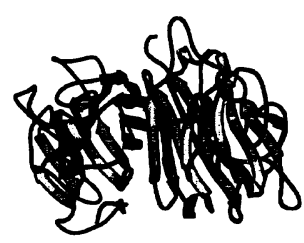

GS4

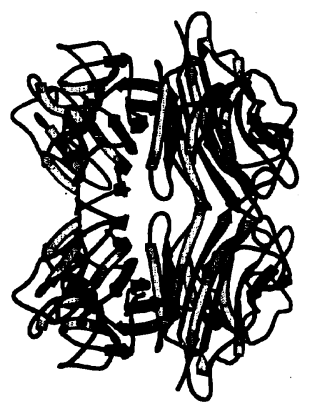

PNA

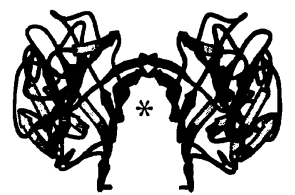

DB58

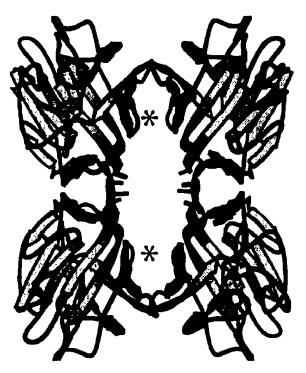

PHA-L

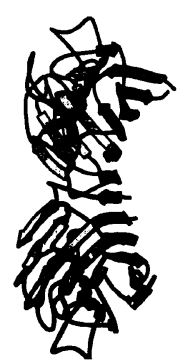

Canonical Dimer

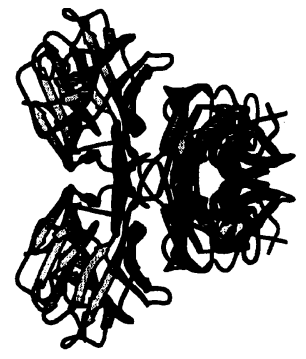

Con A

Fig. 3. The different quaternary structures of the legume lectins. At present, three different tetramer types (Con A, PNA and PHA-L) and three different dimer types are known (the canonical dimer, GS4 and Ecorl). Recently, we discovered a fourth dimer type (DB58, our unpublished results). The known legume lectin tetramers can be considered as "dimers of dimers", so the tetramers and their corresponding dimers are vertically arranged for ease of comparison. Note however that two canonical dimers are present in both Con A and PHA-L, but that PHA-L can also be considered as a dimer of DB58 dimers. The putative adenine binding sites in DB58 and PHA-L are indicated with an asterisk. Peanut agglutinin contains one canonical dimer and two GS4 dimers. There is no known tetramer that contains the Erythrina corallodendron lectin type dimer.

\section{Quaternary structure}

One of the unique features of the legume lectins is their variable quaternary structure : although the structures of their monomers are highly similar, they can associate in a number of different tetramers and dimers. At present three different tetramer types and three different dimer types have been published and recently our group discovered a fourth dimer type (see Fig. 3 ). The so-called canonical dimer consists of two monomers that associate via the formation of a continuous twelve strand $\beta$ sheet out of two flat back sheets, along the length of the dimer. This quaternary structure is adopted by pea lectin (43), favin (44), lentil lectin (45), the Lathyrus ochrus isolectins (34) and the $\alpha$-amylase inhibitor from Phaseolus vulgaris (46), which is a truncated lectin (see below). The three other dimer types each have only one representative. In the GS4 dimer (40), two flat back sheets pack face to face with their $\beta$-strands running perpendicular to each other. In the EcorL dimer (25), the dimer interface consists mainly of side chains belonging to the two upper $\beta$-strands of the back sheet.

We recently determined the quaternary structure of the stems and leaves lectin from Dolichos biflorus (DB58). In this

\section{D. 四次構造}

マメ科レクチンの最も際立った特徴の一つは、その多様な 四次構造である。各々の単量体の構造は高度に類似している が、それらは多くの異なる四量体、および二量体に会合でき る。現在までに、異なる3つの型の四量体と、異なる3つの型の 二量体が報告されており、また最近著者らは第 4 の型の二量体 を見い出した(図3)。いわゆる標準二量体は、2個の単量体が2枚 の平らな背面折り紙構造から、二量体の長軸に沿って連続的な 12本のペプチド鎖を含む1枚の $\beta$-シートを形成することにより 会合している。エンドウマメレクチン(43)、ソラマメレクチン (44)、レンチルレクチン(45)、ヒゲレンリソウ(Lathyrus ochrus)イ ソレクチン(34)、および切断されたレクチンであるインゲンマメ

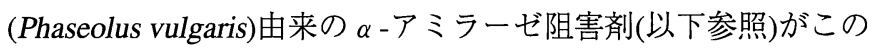
ような四次構造をとっている。それ以外の3つの型の二量体には それぞれ一つだけの見本がある。GS4二量体(40)では、2つの背 面折り紙構造が、互いの平面から垂直に伸びた $\beta$-鎖によって向 かい合わせに固定される。EcorL二量体(25)では、二量体の接触 面は主に背面折り紙構造の上部の $\beta$-鎖に属する 2 本の側鎖に よって構成されている。

われわれは最近、Dolichos biflorusの茎および葉由来のレク チン(DB58)の四次構造を決定した。この二量体においては、2個 
dimer, the two monomers associate with their flat back sheets facing each other. The small side chains (Ile, Ser) of the upper $\beta$-strand of the back sheet intercalate and form a tight interface. In addition, the $\mathrm{C}$ terminus of one of the two monomers positions itself in the central cavity, while the $\mathrm{C}$-terminus of the other monomer is truncated, resulting in the formation of a heterodimer (47). This C-terminal stretch is not included in the model because the density is hard to interpret, due to two-fold averaging of the density.

Con $\mathrm{A}$, the first legume lectin structure reported (48), consists of two canonical dimers that pack against each other with the central parts of their continuous twelve strand $\beta$-sheets. The $\beta$-strands of the two dimers are at an angle of almost $90^{\circ}$, and the interface consists mainly of electrostatic interactions. The Con A tetramer has been crystallized in different space groups, and shows that the Con A tetramer is quite flexible : small rotations and/or translation of the subunits are possible $(24,49)$. This is also illustrated by a naturally occurring "mutant" of Con A from Canavalia brasiliensis, whose quaternary structure differs slightly from the other Con A structures, presumably due to a mutation (Asp58Gly) at the dimer-dimer interface (50).

Peanut agglutinin $(7,51)$ forms a tetramer that can be considered as an association of two GS4 dimers. These two GS4 dimers associate via the formation of a canonical dimer, formed by one monomer from each GS4 dimer. The peanut tetramer is unique because it is the only known homotetramer that does not possess 222 or 4 fold symmetry.

Finally, the PHA-L tetramer (42) can be viewed in two different ways : as a dimer of two canonical dimers, or as a dimer of two DB58 dimers. This mode of association creates a big channel in the center of the molecule, twice as large as the channel in DB58. In this channel, two C-terminal stretches are positioned (26), while the two other C-terminal stretches are truncated (52). In addition, this channel is also believed to harbor the adenine binding site found in a number of tetrameric and dimeric legume lectins (see paragraph 4). The PHA-L tetramer type can probably be called the canonical tetramer type, because it is adopted by PHA-L, SBA (26), DBL (our unpublished results), Vicia villosa isolectin B4 (53) and Ulex europaeus lectin II (84). All these lectins contain the sequence Ser-X-Ile$\mathrm{X}$-Ser in the outer strand of the front sheet, except UEA-II which contains Ser-X-Ile-X-Thr and the Vicia villosa isolectin B4 for which this part of the sequence is unknown.

It is remarkable that three of the four dimer types are also found in the tetramers : the canonical dimer is found in the Con A, PHA-L and peanut agglutinin tetramers; the GS4 dimer is found in peanut agglutinin, and the DB58 dimer is found in PHA-L. Only the EcorL dimer has not (yet?) been found in any tetramer type.

Remarkably, lectins that share no sequence identity with
の単量体が平らな背面折り紙構造を向かい合わせて会合してい る。背面折り紙構造の上部 $\beta$-鎖の小さい側鎖(Ile, Ser)が挿入 し、しっかりとした界面を形成する。さらに、2個の単量体のう ち1個のC-末端がその中央の空洞に位置し、もう一方のC-末端が 切断され、結果としてへテロ二量体が形成される(47)。密度の2 倍平均となるため密度の解釈が困難なので、このC-末端の伸長 はモデルに含まれていない。

マメ科レクチンの構造として最初に報告されたCon A (48)、連続的な 12 本のペプチド鎖からなる $\beta$-シートの中央部分 で互いに固定された、2個の標準二量体から成る。2個の二量体 の $\beta$-鎖は、ほほ $90^{\circ}$ 角度を成し、その境界面は主に静電的相互作 用で構成される。Con A四量体は異なる空間群に結晶化され、た いへん柔軟性が高いことが示された:すなわちサブユニットの小 さな回転や変形が可能である(24、49)。このことは、Canavalia brasiliensis由来の天然に生じた“突然変異体”Con Aによっても 説明される。この四次構造は他のCon A構造とわずかに異なり、 おそらく二量体-二量体の境界面にある1つの突然変異(Asp58Gly) のためと考えられる $(50)$ 。

ピーナツ凝集素(7、51)は四量体を形成するが、これは 2 個 のGS4二量体の会合体であると考えられる。これら 2 個の GS4 二量体は、各二量体から 1 個ずつの単量体が標準二量体を形成 することによって会合する。ピーナツ四量体は、既知のホモ四 量体の中で 222 または 4 回対称を持たない唯一のものとして、 珍しい。

最後に、PHA-L四量体(42)については異なる2つの見方、 すなわち標準二量体の二量体またはDB58二量体の二量体、とい うとらえ方が考えられる。この会合様式は、分子の中央にDB58 の溝のおよそ2倍の大きさの巨大な溝を作り出した。この溝には 2本のC-末端鎖が伸び(26)、残りの2本のC-末端は切断されている (52)。さらにこの溝には、多くの四量体および二量体のマメ科レ クチンに見い出されるアデニン結合部位があると信じられてい る(E 節参照)。PHA-L、SBA(26)、DBL(著者ら、未発表)、ビ ロードクサフジ(Vicia villosa)イソレクチンB4(53)、およびハリエ ニシダレクチンIIUEA-II、著者ら、未発表)も、この型の四量体 を形成しているので、PHA-L四量体型はおそらく標準四量体と 呼ぶことができるであろう。これらのレクチンはすべて前面折 り紙構造の外部鎖にSer-X-Ile-X-Serという配列を持っているが、 UEA-IIはSer-X-Ile-X-Thrという配列を含み、ビロードクサフジイ ソレクチンB4のこの部分に相当する配列は不明である。

二量体の4つの型のうち3つは四量体中でも見つかっている ことは注目すべき点である。すなわち、標準二量体はCon A、 PHA-L、およびピーナツ凝集素の四量体中に、GS4二量体は ピーナツ凝集素中に、そしてDB58二量体はPHA-L中に見い出さ れた。EcorL二量体だけは(まだ?)どんな四量体型にも見い出さ れていない。 
the legume lectins can form similar multimers. The galectins are Gal-specific mammalian lectins that possess the same fold as the legume lectins, although the position of the sugar binding site differs from the legume lectins. The galectin dimers of a human galectin (9) and bovine spleen galectin (10) resemble a canonical legume lectin dimer, although two continuous $\beta$-sheets are running along the length of the dimer instead of one.

Recently, the crystal structures of two lectins from the spermadhesin family, which is involved in sperm-egg binding in mammalia, were published (aSFP and PSP-I/PSP-II, (16-18)). Their subunits are highly similar and consist of a $\beta$-sandwich with a jellyroll related topology that contains two five stranded $\beta$-sheets, an architecture that is also found in the legume lectins and the galectins but with a different topology. Remarkably, the monomeric aSFP forms a canonical dimer in the crystal (16), while the PSP-I/PSP-II heterodimer, which shows some similarity to the EcorL dimer, forms a tetramer in the crystal via the formation of what resembles a canonical dimer (17), which is reminiscent of the PNA tetramer. It is not known whether the aSFP dimer and the PSP-I/PSP-II tetramer fulfill some physiological role.

What is the reason behind this remarkable variability of quaternary structures in the legume lectins? Multivalent lectins have been shown in vitro to form cross-linked lattices, sometimes even macroscopic crystals $(6,26,54-57)$, with oligosaccharides that contain multiple epitopes. In vivo, cross linking of receptors is an important way of transferring signals $(58,59)$. Two lectins with an identical specificity, but with a different quaternary structure will necessarily form different cross-linked lattices with the same epitope. Hence, variability of quaternary structure can be used to obtain the correct cross-linked lattice or to maximize the avidity towards structures bearing multiple epitopes.

\section{E. Hydrophobic Binding Sites in Legume Lectins}

Some legume lectins also possess hydrophobic binding sites that do not interfere with the sugar binding sites $(60,61)$. The function of these binding sites in vivo remains obscure, but the fact that these sites are present in legume lectins from different species suggests that they play a specific biological role. One of these binding sites shows a high affinity $\left(10^{6} \mathrm{M}^{-1}\right)$ for adenine and certain adenine derivatives (62). This site has been found in tetrameric legume lectins (PHA-L (Jan Backmann, personal communication), PHA-E (63), LBL (61-63), SBA (63), hog peanut lectin (Amphicarpaea bracteata) (64) and DBL (63, $65,66)$ ) and dimeric lectins (winged bean (Phosphocarpus tetragonolobus) agglutinin (67) and DB58 $(65,66)$ ). Binding studies suggest that one or two sites per molecule are present in tetrameric adenine binding lectins. The residues involved in the formation of the adenine binding site of PHA-E and LBL have been determined by photoaffinity labeling with 8 -azidoadenine
マメ科レクチンと配列に一致する部分のないレクチンも、 同様の多量体を形成できるということは特徵的である。Gal特異 的な哺乳類レクチンであるガレクチンは、マメ科レクチンと糖 結合部位の位置は異なるが、同じ折り畳み構造を持っている。

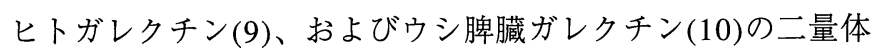
は、1枚ではなく2枚の連続的な $\beta$-シートが二量体の長軸に沿っ てならんでいるが、マメ科レクチンの標準二量体に類似してい る。

最近、哺乳類の精子-卵結合に関与するスパームアドヘジン ファミリー由来の 2 種類のレクチンの結晶構造が報告された (aSFP,PSP-I/PSP-II (16-18))。それらのサブユニットは高度に類似 しており、ポリペプチド鎖5 本からなる2枚の $\beta$-シートを含むゼ リーロール構造関連のトポロジーをもつ $\beta$-サンドイッチで構成 され、マメ科レクチンにもガレクチンにも見い出される構築で あるが、そのトポロジーは異なる。単量体のaSFPは、結晶中で は標準二量体を形成し(16)、一方、EcorL二量体にいくらか類似 性を示すPSP-I/PSP-IIへテロ二量体は、結晶中ではPNA四量体を 想起させる標準二量体に類似したものの形成を経て、四量体を 形成する(17)。aSFP二量体およびPSP-I/PSP-II四量体が、なんら かの生理学的な役割を果たしているかどうかは不明である。

マメ科レクチンにおける際立った四次構造の多様性には、 どんな理由が隠されているのだろうか? 多価のレクチンはin vitroにおいて、多様なエピトープを持つオリゴ糖鎖とともに架 橋格子を形成し、時として肉眼で見える結晶になることもある (6、26、54-57)。In vivoにおいて、受容体の架橋は情報伝達に重 要な手段である(58、59)。同一の特異性を持ち、異なる四次構造 をとる2種類のレクチンは、同じエピトープに対して異なる架橋 格子を形成するに違いない。したがって、四次構造の多様性は 正しい架橋格子を得るため、または複数のエピトープを持つ構 造に対して結合力(avidity)を最高にするために用いられる可能性 がある。

\section{E. マメ科レクチンにおける疎水的結合部位}

いくつかのマメ科レクチンは、糖結合部位を妨げないよう な疎水的結合部位を持っている(60、61)。In vivoにおけるこれら の結合部位の機能については不明瞭だが、異なる種のマメ科レ クチンにこれらの部位が存在しているという事実から、特異的 な生物学的役割を担っていることが示唆される。これらの結合 部位の1つはアデニンやある種のアデニン誘導体に対して高親和 性 $\left(10^{6} \mathrm{M}^{-1}\right)$ を示す $(62)$ 。この部位は四量体マメ科レクチン (PHAL(Jan Backmann, 私信), PHA-E(63), LBL(61-63), SBA(63)、ヤブ

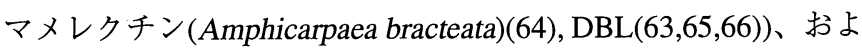
び二量体レクチン(winged bean (Phosphocarpus tetragonolobus) 血 球凝集素(67)、DB58(65、66))に見い出された。結合試験から、 アデニン結合性四量体レクチン中には、一分子あたり1つあるい は2つの結合部位が存在することが示唆された。PHA-Eおよび 
Trends in Glycoscience and Glycotechnology Vol.10 No.55 (September 1998) pp.349-360

(68). The two isolated photolabeled peptides had an overlapping stretch of five residues in common $\left(\mathrm{V}^{185} \mathrm{LITY}\right.$ in PHA-E). This stretch is found in a $\beta$-sheet of the flat back sheet and lines the central channel in the PHA-L and SBA tetramers, in the vicinity of the dimer-dimer interfaces. Because of the 222 symmetry of these tetramers, two stretches face each other, thereby creating a pocket with a 2-fold symmetry. Apparently, adopting a PHA-L-like tetramer is important for the formation of the adenine binding site. The fact that DB58 binds adenine despite being a dimer can then be explained by its remarkable quaternary structure : it is formed by two monomers that face each other, thus forming a channel that is half as big as the channel in PHA-L (see Fig. 3).

\section{F. Arcelin and $\alpha$-Amylase Inhibitor : Two Truncated Le- gume Lectins}

The arcelins and $\alpha$-amylase inhibitors ( $\alpha \mathrm{AI})$ (69) from the seeds of the common bean are both groups of legume lectin homologues, but they do not bind sugars and hence are not lectins. Both proteins protect the bean seeds against predation by insects, and are potentially interesting for crop protection via genetic engineering (70). Arcelin is present in certain wild bean strains and confers resistance against the bean pest Zabrotes subfasciatus (71). Its working mechanism remains obscure, however. $\alpha \mathrm{AI}$ inhibits $\alpha$-amylase from mammals and insects, but not from bacteria, fungi or plants, and transgenic pea plants expressing $\alpha \mathrm{AI}$ become resistant against certain Bruchid beetles (72).

The crystal structure of arcelin- $5(73,74)$ was solved at a resolution of $2.7 \AA$. Arcelin- 5 crystallized as a monomer whose overall structure resembles the structure of the legume lectin monomers. However, the metal binding loop found in all the legume lectins is truncated in arcelin-5: five of the six residues corresponding to the metal ligands are either absent or inappropriate for metal ligation. Despite the absence of the bound metal ions, the $c i s$-peptide bond found in all the legume lectins is still present, but the Asp residue is replaced by a Tyr residue. Strikingly, an Ala-Tyr or Ala-Phe sequence is found in all known arcelin sequences, suggesting that this unexpected cis-peptide bond may be involved in the function of the protein.

A complex of the $\alpha$ AI with porcine pancreas $\alpha$-amylase was solved at a resolution of $1.8 \AA$ (46). The $\alpha$ AI monomer is similar to a true legume lectin monomer, although two sugar binding loops are truncated. The first truncated loop corresponds to the truncated metal binding loop in arcelin-5, while the second loop is the large $\Omega$-loop that contains the Gly residue of the conserved Gly-Asn-Asp triad. Two $\alpha$ AI monomers form a canonical dimer, and each subunit mainly interacts with the active site of one $\alpha$-amylase molecule via two loops. The structure of these two loops is stabilized by a $\mathrm{Ca}^{2+}$ ion, and differs from the equivalent regions in the legume lectins. Interestingly, the sec-
LBLのアデニン結合部位の形成に関与している残基は、8-アジ ドアデニンによる光親和性標識によって決定された(68)。2つの 単離された標識ペプチドは、5残基の部分的に重複する配列を共

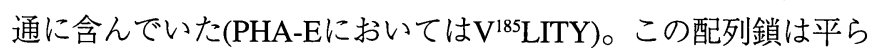
な背面折り紙構造の $\beta$-シート中に見い出され、PHA-Lおよび SBA四量体の中央の溝部で二量体-二量体境界面の近くに位置し ている。これらの四量体は222対称を持つため、2つの配列鎖は 互いに面し、その結果として2回対称性を持つポケットを作り出 す。明らかに、PHA-L様の四量体構造をとることはアデニン結 合部位を形成するために重要である。するとDB58が二量体であ るにも関わらずアデニンと結合する事実は、その顕著な四次構 造から次のように説明できる。すなわち、2個の単量体が向かい 合うことによって、PHA-Lにおける溝の半分の大きさの溝が形 成される(図3)。

F. Arcelinと $\alpha$-アミラーゼ阻害剤：2つの切断されたマメ 科レクチン

共通のマメ科種子由来の arcelinと $\alpha$-アミラーゼ阻害剤 $(\alpha \mathrm{AI})$ は、ともにマメ科レクチングループの相同タンパク質である が、いずれも糖とは結合せず、したがってレクチンではない。 これらのタンパク質は昆虫による捕食から種子を守り、遺伝子 工学を通じた農作物保護の可能性への興味をそそる(70)。Arcelin はある種の野性マメ株中に存在し、マメの害虫であるZabrotes subfasciatusに対して抵抗力を与える(71)。しかし、その作用機構 はまだはっきりしない。 $\alpha$ AIは哺乳動物や昆虫の $\alpha$-アミラーゼ 活性を阻害するが、バクテリア、菌類、および植物由来の $\alpha$-ア ミラーゼ活性については阻害せず、 $\alpha$ AIを発現する形質転換した エンドウマメはある種の甲虫(Bruchid beetle)に対して耐性になる (72)。

Arcelin-5の結晶構造は解像度 $2.7 \AA ̊$ で解析された $(73 、 74) 。$ 単量体として結晶化されたarcelin-5の全体の構造は、マメ科レク チンの単量体の構造に類似している。しかし、全てのマメ科レ クチンに見い出される金属結合ループは、 arcelin-5では切断され ている。すなわち、金属リガンドとの結合に関与する6残基のう ち5つが存在しないか、または金属との結合に不適当であった。 結合金属イオンが存在しないにもかかわらず、全てのマメ科レ クチンに見い出されるシスーペプチド結合は存在しているが、 Asp残基がTyr残基に置換されていた。注意をひくこととして、 既知のすべてのarcelin配列中にAla-TyrまたはAla-Phe配列が見い 出され、この予想外のシスーペプチド結合はこのタンパク質の機 能に関係している可能性が示唆される。

$\alpha \mathrm{AI}$ とブ夕膵臓 $\alpha$-アミラーゼの複合体が解像度 $1.8 \AA$ で解析 された(46)。aAI単量体は、2つの糖結合ループが切り取られてい るが、マメ科レクチン単量体と類似している。第1の切断された ループはarcelin-5の金属結合ループに相当し、第2のループは保 存されたGly-Asn-Asp3つ組のGly残基を含む大きな $\Omega$-ループで ある。2個の $\alpha \mathrm{AI}$ 単量体は標準二量体を形成し、それぞれのサブ

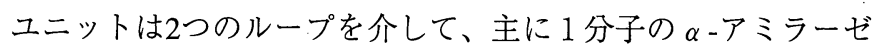

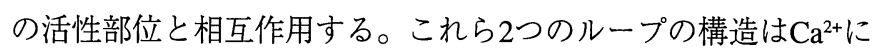
よって安定化され、マメ科レクチンにおいて等価な領域とは異 
ond loop corresponds to the monosaccharide specificity loop in the legume lectins.

Truncated lectins are also found outside the legume lectin family. Lythostatine (75), a protective protein from human pancreas, and blood coagulation factors IX/X binding protein (IX/X-bp) (76), a snake venom component, are truncated C-type lectins. Charcot-Leyden crystal protein (19), found in human eosinophils, is a truncated galectin with lysophospholipase activity.

\section{G. Homologues Outside the Leguminosae Family}

A few years ago, it was shown that animals contain legume lectin homologues. At present two such homologues have been described : VIP36 and ERGIC-53 are integral membrane proteins that contain domains which have 19 and $24 \%$ identity with the legume lectins, respectively (77). Three conserved sugar binding residues (the Asn-Gly-Asp triad) are present in both VIP36 and ERGIC-53. VIP36 is present in the Golgi apparatus, in transport vesicles and on the cell surface and is thought to be involved in glycoprotein sorting. Similarly, ERGIC-53 is present in the intermediate region between the endoplasmatic reticulum and the Golgi apparatus, and is thought to be involved in transport of glycoproteins from the endoplasmatic reticulum to the Golgi apparatus. It has been shown that VIP36 contains two $\mathrm{Ca}^{2+}$ binding sites, although unlike the legume lectins VIP36 does not bind $\mathrm{Mn}^{2+}$ (78). In addition, GalNAc could inhibit binding of VIP36 to putative endogenous ligands in an immunofluorescence assay. ERGIC-53 is a calcium dependent mannose specific lectin, and mutational analyses have shown that at least two of the three putative sugar binding residues are important for carbohydrate binding (79).

The legume lectins are not the only plant lectin family for which animal homologues have been found. Comitin is a 48 $\mathrm{kD}$ actin-binding dimer that is primarily found on Golgi and vesicle membranes and is homologous to the mannose-specific monocotyledon lectins (80). Comitin is thought to attach vesicles to the cell skeleton via an actin-binding domain that binds to the skeleton on the one hand and a Man specific lectin domain that binds to exposed Man residues on the surface of the vesicles, on the other hand.

These exciting examples could lead to an interesting new direction in the field of "plant" lectin studies. Moreover, they point to the necessity of finding a new name for the so-called "legume lectin family". Not only have two homologues of this family been found in mammals, but a receptor-like serine/threonine kinase from Arabidopsis thaliana (Brassicaceae) homologous to the legume lectins has also been reported (81).

\section{H. Conclusions}

The (selected) topics treated in this review hopefully give a good impression of the tremendous amount of work that has
なる。興味深いことに第2のループはマメ科レクチンの単糖特異 性ループに相当する。

切断されたレクチンはマメ科レクチンファミリー以外にも 見い出されている。ヒト膵臓由来の防御タンパク質である lythostatine (75)、およびへビ毒成分である血液凝固因子IX/X結合 タンパク質(IX/X-bp) (76)は切断されたC型レクチンである。ヒト の好酸球に存在するシャルコー・ライデン結晶タンパク質(19)は リゾホスホリパーゼ活性を持つ切断されたガレクチンである。

\section{G. マメ科ファミリー以外での相同タンパク質}

数年前、動物がマメ科レクチンの相同タンパク質を持って いることが明らかとなった。現在までに、そのような相同タン パク質は2つ報告されている。すなわち、VIP36およびERGIC-53 で、これらは膜貫通型タンパク質であり、マメ科レクチンとそ れぞれ19および24\%一致するドメインを含んでいる(77)。また、 VIP36およびERGIC-53は両方とも保存された糖結合残基(AsnGly-Aspの三つ組)を持っている。VIP36はゴルジ装置中、輸送小 胞中、および細胞表面上に存在し、糖タンパク質の選別に関与 していると考えられている。同様に、ERGIC-53は小胞体とゴル ジ装置の中間領域に存在し、小胞体からゴルジ装置への糖タン パク質の輸送に関与していると考えられている。VIP36は、マメ 科レクチンと異なり $\mathrm{Mn}^{2+}$ とは結合しないが、2つの $\mathrm{Ca}^{2+}$ 結合部位 を持つことが示されている(78)。ささらに免疫蛍光分析から、推定 上の内因性リガンドとVIP36の結合はGalNAcで阻害された。 ERGIC-53はC $a^{2+}$ 依存性Man特異的レクチンで、突然変異による 実験から糖との結合には、推定上の糖結合 3 残基のうち少なくと も2残基が重要であることが示された(79)。

マメ科レクチンは動物に相同タンパク質が見つかった唯一 の植物レクチンファミリーではない。Comitinは、主にゴルジや 小胞膜中に見い出される $48 \mathrm{kD}$ のアクチン結合性二量体である が、Man特異的単子葉植物レクチンに相同性がある $(80)$ 。 Comitinは、一方では細胞骨格に結合するアクチン結合ドメイン と、他方では小胞表面上の露出したMan残基に結合するMan特異 的レクチンドメインを介して、小胞を細胞骨格に付着させると 考えられている。

これらの刺激的な例は、“植物”レクチンの研究分野に対 して興味深い新たな方向性を与えてくれる。そればかりでな く、いわゆる“マメ科レクチンファミリー”に対して新しい名前 を見つけなくてはならないことを示している。このファミリー の2つの相同タンパク質が哺乳動物に見い出されただけでなく、 シロイヌナズナ(Arabidopsis thaliana (Brassicaceae))由来の受容体 様Ser/Thrキナーゼもまたマメ科レクチン相同タンパク質である ことが報告されている(81)。

\section{H. 結 論}

この総説で取り上げた選り抜きの論題が、今までに達成さ 
already been done, and of the exciting secrets that have yet to be revealed. Indeed, large pieces of the puzzle are still missing. Structural data on Fuc and GlcNAc/GlcNAc( $\beta 1-4)$ GlcNAc specific lectins is still lacking, and only one sugar complex of a legume lectin with complex specificity has been published (41). Structural characterization of a mammalian homologue and comparison with its plant relatives could lead to interesting new insights.

As a final remark, we would like to draw attention to the highly surprising fact that there is still no general consensus about the role of the legume lectins in vivo, despite the huge amount of work that has been invested and especially in the light of the fairly well documented function of their more recently discovered mammalian counterparts. Maybe some clue is the fact that some legume lectins possess a high affinity $\left(10^{6} \mathrm{M}^{-1}\right)$ binding site for adenine and adenine derivatives. In any case, the lack of knowledge about their in vivo function has not hampered their use as a model system in the past, and they will probably continue to be used in the future.

れた膨大な仕事と今後明らかにされるべき刺激的な秘密につい て、良い印象を与えたことだろう。実際に、まだ多くの難題が 残されている。FucおよびGlcNAc/GlcNAc( $\beta 1-4)$ GlcNAc特異的レ クチンの構造的データはまだ不足しており、複雑な特異性を 持った1種類のマメ科レクチンの1つの糖結合複合体しか報告さ れていない(41)。哺乳類相同タンパク質の構造的な特性と植物と の比較は、新たに興味深い視点を与えるだろう。

最後に、われわれはとても驚くべき事実に注意を促したい と思う。それは、既に投資された膨大な仕事および、最近発見 された哺乳動物の相同タンパク質でかなりよく裏付けられた機 能に照らしてもなお、in vivoに扔けるマメ科レクチンの役割に ついて一般的な合意がまだないということである。扔そらく何 らかの手がかりは、いくつかのマメ科レクチンがアデニンおよ びアデニン誘導体に対して高親和性 $\left(10^{6} \mathrm{M}^{-1}\right)$ 結合部位を持つとい う事実にあるのだろう。いずれにしても、in vivoにおけるこれ らの機能に関する知識の不足は、過去にモデルシステムとして これらを用いることには何の妨げにもならなかったし、これか らもそうあり続けるであろうが。

\section{お茶の水女子大学大学院 $\cdot$ 人間文化研究科 $\cdot$ 人間環境科学専攻} 上田 晴子 訳

\section{References}

1. Sharon, N., and Lis, H. (1990) FASEB J. 4, 3198-3208

2. Loris, R., Hamelryck, T., Bouckaert, J., and Wyns, L. (1998) Biochem. Biophys. Acta 1383, 9-36

3. Drickamer, K. (1997) Structure 5, 465-468

4. Weis, W.I. and Drickamer, K. (1996) Annu. Rev. Biochem. 65, 441-473

5. Rini, J.M. (1995) Annu. Rev. Biophys. 24, 551-577

6. Brewer, C.F. (1996) Chemtracts Biochem. Mol Biol. 6, 165-179

7. Banerjee, R., Das, K., Ravishankar, R., Suguna, K., and Surolia, A. (1996) J. Mol. Biol. 259, 281-296

8. Stirk, H.J., Woolfson, D.N., Hutchinson, E.G., and Thornton, J.M. (1992) FEBS lett. 308, 1-3

9. Lobsanov, Y.D., Gitt, M.A., Leffler, H., Barondes, S.H., and Rini, J.M. (1993) J. Biol. Chem. 268, 27034-27038

10. Liao, D., Kapadia, G., Ahmed, H., Vasta, G.R., and Herzberg, O. (1994) Proc. Natl. Acad. Sci. USA 91, 1428-1432

11. Emsley, J., White, H.E., O’Hara, B.P., Olivia, G., Srinivasan, N., Tickle, I.J., Blundell, T.L., Pepys, M.B., and Wood, S.P. (1994) Nature 367, 338-345

12. Keitel, T., Simon, O., Borris, R., and Heinemann, U. (1993) Proc. Natl. Acad. Sci. USA 90, 5287-5291

13. Norris, G.E., Stillman, T.J., Anderson, B.F., and Baker, E.N. (1994) Structure 2, 1049-1059

14. Kuhn, P., Tarentino, A.L., Plummer, T.H., and Van Roey, P. (1994) Biochemistry 33, 11699-11706

15. Divne, C., Stahlberg, J., Reinikainen, T., Ruohonen, L., Petterson, G., Knowles, J.K.C., Teeri, T.T., and Jones, T.A. (1994) Science 265, 524528

16. Romao, M.J., Kölln, I., Dias, J.M., Carvalho, A.L., Romero, A., Varela, P.F., Sanz, L., Töpfer-Petersen, E., and Calvete, J.J. (1997) J. Mol. Biol. 274, 650-660

17. Varela, P.F., Romero, A., Sanz, L., Romao, M.J., Töpfer-Petersen, E., and Calvete, J.J. (1997) J. Mol. Biol. 274, 635-649

18. Romero, A., Romao, M.J., Varela, P.F., Köln, I., Dias, J.M., Carvalho, A.L., Sanz, L., Töpfer-Petersen, E., and Calvete, J.J. (1997) Nat. Struct. Biol. 4, 783-787

19. Leonidas, D.D., Elbert, B.L., Zhou, Z., Leffler, H., Ackerman, S.J., and Acharya, K.R. (1995) Structure 3, 1379-1393

20. Etzler, M.E., and Kabat, E.A. (1970) Biochemistry 9, 869-877

21. Bouckaert, J., Loris, R., Poortmans, F., and Wyns, L. (1995) Prot. Struct. Func. Gen. 23, 510-524

22. Bourne, Y., Roussel, A., Frey, M., Rougé, P., Fontecilla-Camps, J. C., and Cambillau, C. (1990) Prot. Struct. Func. Gen. 8, $365-376$

23. Loris, R., Casset, F., Bouckaert, J., Pletinckx, J., Dao-Thi, M., Poortmans, F., Imberty, A., Pérez, S., and Wyns, L. (1994) Glycoconjugate J. 11, 507-517

24. Naismith, J.H., Emmerich, C., Habash, J., Harrop, S.J., Helliwell, J.R., Hunter, W.N., Raftery, J., Kalb(Gilboa), A.J., and Yariv, J. (1994) Acta Cryst. D50, 847-858

25. Shaanan, B., Lis, H., and Sharon, N. (1991) Science 254, 862-865

26. Dessen, A., Gupta, D., Sabesan, S., Brewer, F., and Sacchettini, J.C. (1995) Biochemistry 34, 4933-4942

27. Sharma, V., and Surolia, A. (1997) J. Mol. Biol. 267, 433-445

28. Gohier, A., Espinosa, J.F., Jimenez-Barbero, J., Carrupt, P.A., Pérez, S., and Imberty, A. (1996) J. Mol. Graph. 14, 322-327

29. Kanellopoulos, P.N., Pavlou, K., Perrakis, A., Agianan, B., Vorgias, C.E., Mavrommatis, C., Soufi, M., Tucker, P.A., and Hamodrakas, S.J. (1996) J. Struct. Biol. 116, 345-355

30. Moreno, E., Teneberg, S., Adar, R., Sharon, N., Karlsson, K., and Angström, J. (1997) Biochemistry 36, 4429-4437 
31. Kornfeld, K., Reitman, M.L., and Kornfeld, R. (1981) J. Biol. Chem. 256, 6633-6640

32. Bourne, Y., Ayouba, A., Rougé, P., and Cambillau, C. (1994) J. Biol. Chem. 269, 9429-9435

33. Imberty, A., Casset, F., Gegg, C. V., Etzler, M.E., and Pérez, S. (1994) Glycoconjugate J. 11, 400-413

34. Bourne, Y., Mazurier, J., Legrand, D., Rougé, P., Montreuil, J., Spik, G., and Cambillau, C. (1994) Structure 2, 209-219

35. Sokolowski, T., Peters, T., Pérez, S., and Imberty, A. (1997) J. Mol. Graph. 15, 37-42

36. Naismith, J.H. and Field, R.A. (1996) J. Biol. Chem. 271, 972-976

37. Loris, R., Maes, D., Poortmans, F., Wyns, L., and Bouckaert, J. (1996) J. Biol. Chem. 271, 30614-30618

38. Casset, F., Peters, T., Etzler, M., Korchagina, E., Nifant'ev, K., Pérez, S., and Imberty, A. (1996) Eur. J. Biochem. 239, 710-719

39. Delbaere, L.T.J., Vandonselaar, M., Prasad, L., Pearlstone, J.R., Carpenter, M.R., Smillie, L.B., Nikrad, P.V., Spohr, U., and Lemieux, R.U. (1990) Can. J. Chem. 68, 1116-1121

40. Delbaere, L.T.J., Vandonselaar, M., Prasad, L., Quail, J.W., Nikrad, P.V., Pearlstone, J.R., Carpenter, M.R., Smillie, L.B., Spohr, U., and Lemieux, R.U. (1989) Transactions ACA 25, 65-76

41. Delbaere, L.T.J., Vandonselaar, M., Prasad, L., Quail, J.W., Wilson, K.S., and Dauter, Z. (1993) J. Mol. Biol. 230, 950-965

42. Hamelryck, T.W., Dao-Thi, M., Poortmans, F., Chrispeels, M. J., Wyns, L., and Loris, R. (1996) J. Biol. Chem. 271, 20479-20485

43. Einspahr, H., Parks, E.H., Suguna, K., Subramanian, E., and Suddath, F.L. (1986) J. Biol. Chem. 261, 16518-16527

44. Reeke, G.N. and Becker, J.W. (1986) Science 234, 1108-1111

45. Loris, R., Steyaert, J., Maes, D., Lisgarten, J., Pickersgill, R., and Wyns, L. (1993) Biochemistry 32, 8772-8980

46. Bompard-Gilles, C., Rousseau, P., Rougé, P., and Payan, F. (1996) Structure 4, 1441-1452

47. Schnell, D.J. and Etzler, M.E. (1988) J. Biol. Chem. 263, 14648-14653

48. Becker, J.W., Reeke, G.N., Wang, J.L., Cunningham, A., and Edelman, G.M. (1975) J. Biol. Chem. 250, 1513-1524

49. Bouckaert, J., Loris, R., and Wyns, L. (1996) in Van Driessche, (eds. E., Rougé, P., Beeckmans, S., and BØg-Hansen, T. C.) pp. 50-60, Textop, Denmark, Hellerup

50. Sanz-Aparicio, J., Hermoso, J., Grangeiro, T., Calvete, J., and Cavada, B. (1997) FEBS lett. 405, 114-118

51. Banerjee, R., Mande, S.C., Ganesh, V., Das, K., Dhanaraj, V., Mahanta, S.K., Suguna, K., Surolia, A., and Vijayan, M. (1994) Proc. Natl. Acad. Sci. USA 91, 227-231

52. Young, M.N., Watson, D.C., Yaguchi, M., Adar, R., Arango, R., Rodriguez-Arango, E., Sharon, N., Blay, P.K.S., and Thibault, P. (1995) J. Biol. Chem. 270, 2563-2570

53. Osinaga, E., Tello, D., Batthyany, C., Bianchet, M., Tavares, G., Durán, R., Cerveñansky, C., Camoin, L., Roseto, A., and Alzari, P.M. (1997) FEBS lett. 412, 190-196

54. Bhattacharyya, L., Khan, M.I., Fant, J., and Brewer, C.F. (1989) J. Biol. Chem. 264, 11543-11545

55. Gupta, D., and Brewer, C.F. (1994) Biochemistry 33, 5526-5530

56. Gupta, D., Bhattacharyya, L., Fant, J., Macaluso, F., Sabesan, S., and Brewer, C. F. (1994) Biochemistry 33, 7495-7504

57. Olsen, L.R., Dessen, A., Gupta, D., Sabesan, S., Sacchettini, J., and Brewer, C.F. (1997) Biochemistry 36, 15073-15080

58. Livnah, O., Stura, E.A., Johnson, D.L., Middleton, S.A., Mulcahy, L.S., Wrighton, N.C., Dower, W.J., Jolliffe, L.K., and Wilson, I.A. (1996) Science 273, 464-471

59. Heldin, C.H. (1995) Cell 80, 213-223

60. Roberts, D.D., and Goldstein, I.J. (1983) Arch. Biochem. Biophys. 224, 479-484

61. Roberts, D.D., and Goldstein, I.J. (1982) J. Biol. Chem. 257, 11274-11277

62. Roberts, D.D., Arjunan, P., Townsend, L.B., and Goldstein, I.J. (1986) Phytochemistry 25, 589-593

63. Roberts, D.D., and Goldstein, I.J. (1983) J. Biol. Chem. 258, 13820-13824

64. Maliarik, M.J., Roberts, D.D., and Goldstein, I.J. (1987) Arch. Biochem. Biophys. 255, 194-200

65. Gegg, C.V., Roberts, D.D., Segel, I.H., and Etzler, M.E. (1992) Biochemistry 31, 6938-6942

66. Gegg, C.V., and Etzler, M.E. (1994) J. Biol. Chem. 269, 5687-5692

67. Puri, K.D., and Surolia, A. (1994) J. Biol. Chem. 269, 30917-30926

68. Maliarik, M.J., and Goldstein, I.J. (1988) J. Biol. Chem. 263, 11274-11279

69. Mirkov, T.E., Wahlstrom, J.M., Hagiwara, K., Finardi-Filho, F., Kjemstrup, S., and Chrispeels, M.J. (1994) Plant Mol. Biol. 26, 1103-1113

70. Chrispeels, M.J. (1997) in Advances in insect control (eds. Carozzi, N., and Koziel, M.) pp. 139-156, London, Taylor \& Francis

71. Osborn, T.C., Alexander, D.C., Sun, S.S.M., Cardona, C., and Bliss, F. A. (1988) Science 240, 207-210

72. Shade, R.E., Schroeder, H.E., Pueyo, J.J., Tabe, L.M., Murdock, L.L., Higgins, T.J.V., and Chrispeels, M.J. (1994) Bio/Technology 12, 793-796

73. Goossens, A., Geremia, R., Bauw, G., Van Montagu, M., and Angenon, G. (1994) Eur. J. Biochem. 225, 787-795

74. Hamelryck, T.W., Poortmans, F., Goossens, A., Angenon, G., Van Montagu, M., Wyns, L., and Loris, R. (1996) J. Biol. Chem. 271, 3279632802

75. Bertrand, J.A., Pignol, D., Bernard, J.P., Verdier, J.M., Dagorn, J.C., and Fontecilla-Camps, J.C. (1996) EMBO J. 15, 2678-2684

76. Mizuno, H., Fujimoto, Z., Koizumi, M., Kano, H., Atoda, H., and Morita, T. (1997) Nat. Struct. Biol. 4, 438-441

77. Fiedler, K., and Simons, K. (1994) Cell 77, 625-626

78. Fiedler, K., and Simons, K. (1995) J. Cell Sci. 109, 271-276

79. Itin, C., Roche, A. C., Monsigny, M., and Hauri, H.P. (1996) Mol. Biol. Cell 7, 483-493

80. Jung, E., Fucini, P., Stewart, M., Noegel, A.A., and Schleicher, M. (1996) EMBO J. 15, 1238-1246

81. Hervé, C., Dabos, P., Galaud, J. P., Rougé, P., and Lescure, B. (1996) J. Mol. Biol. 258, 778-788

82. Casset, F., Hamelryck, T., Loris, R., Brisson, J., Tellier, C., Dao-Thi, M., Wyns, L., Poortmans, F., Pérez, S., and Imberty, A. (1995) J. Biol. Chem. 270, 25619-25628

83. Kraulis, P.J. (1991) J. Appl. Cryst. 24, 946-950

84. Dao-Thi, M.H., Rizkallah, P., Wyns, L., Poorkmans, F., Loris, R. (1998) Acta Cryst. 844-847

Received on February 3, 1998, accepted on February 27, 1998 


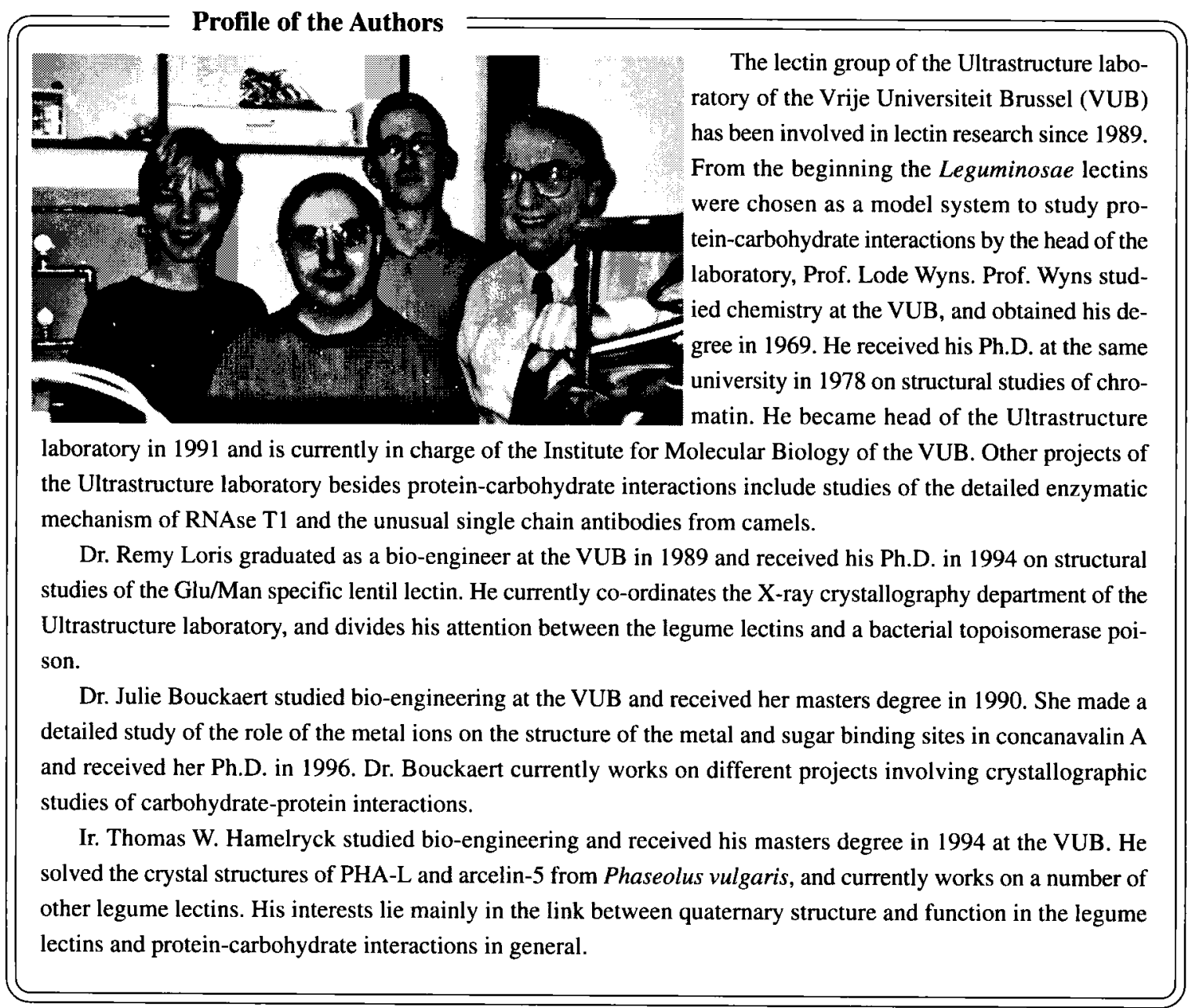

